\title{
Antineoplastic activities of MT8I and its structural analogue in ehrlich ascites carcinoma-bearing swiss albino mice
}

\author{
Sujata Maiti Choudhury,'** Malaya Gupta² and Upal Kanti Majumder²
}

'Department of Human Physiology with Community Health; Vidyasagar University; Midnapore, West Bengal India; ${ }^{2}$ Department of Pharmaceutical Technology; Jadavpur University; Kolkata, West Bengal India

Key words: antitumor activity and antioxidant status, MT81 and its acetic acid derivative, ehrlich ascites carcinoma, mean survival time, hematological parameters

\begin{abstract}
Many fungal toxins exhibit in vitro and in vivo antineoplastic effects on various cancer cell types. Luteoskyrin, a hydroxyanthraquinone has been proved to be a potent inhibitor against Ehrlich ascites tumor cells. The comparative antitumor activity and antioxidant status of MT8I and its structural analogue [Acetic acid-MT8I (Aa-MT8I)] having polyhydroxyanthraquinone structure were assessed against Ehrlich ascites carcinoma (EAC) tumor in mice. The in vitro cytotoxicity was measured by the viability of EAC cells after direct treatment of the said compounds. In in vivo study, MT8I and its structural analogue were administered (i.p.) at the two different doses (5, $7 \mathrm{mg} \mathrm{MT8I}$; 8.93, II.48 mg Aa-MT8I/kg body weight) for 7 days after 24 hrs. of tumor inoculation. The activities were assessed using mean survival time (MST), increased life span (ILS), tumor volume, viable tumor cell count, peritoneal cell count, protein percentage and hematological parameters. Antioxidant status was determined by malondialdehyde (MDA) and reduced glutathione (GSH) content, and by the activity of superoxide dismutase (SOD) and catalase (CAT). MT8I and its structural analogues increased the mean survival time, normal peritoneal cell count. They decreased the tumor volume, viable tumor cell count, hemoglobin percentage and packed cell volume. Differential counts of WBC, total counts of RBC \& WBC that altered by EAC inoculation, were restored in a dose-dependent manner. Increased MDA and decreased GSH content and reduced activity of SOD, and catalase in EAC bearing mice were returned towards normal after the treatment of MT8I and its structural analogue. Being less toxic than parent toxin MT8I, the structural analogue showed more prominent antineoplastic activities against EAC cells compared to MT8I. At the same time, both compounds exhibit to some extent antioxidant potential for the EAC-bearing mice.
\end{abstract}

\section{Introduction}

Cancer is one of the most dreaded diseases of the $20^{\text {th }}$ century. It is the single most common cause of deaths and spreading further with continuance in $21^{\text {st }}$ century in both developed and developing countries. ${ }^{1,2}$ Statistics show that men are largely plagued by lung, colon, rectal and prostate cancer, while women increasing suffer from breast, stomach, colon and rectal cancer. From literature it is revealed that many natural products are available as chemo-preventive agents against commonly occurring cancer types. However, there is continuing need for identification, characterization and development of new chemo-preventive agents from enormous pool of synthetic, biological and natural products.

About $60 \%$ of currently used anticancer agents are obtained from natural sources, including plants, marine organisms and microorganisms. Fungal toxins (mycotoxins) though known to be toxic to the animal and human systems still find their use in therapeutic application. Mycophenolic acid, ${ }^{3}$ penicillic acid, ${ }^{4}$ 5-methoxy-sterigmatocystin, ${ }^{5}$ a series of analogues of anguidine, ${ }^{6,7}$ including triacetoxyscirpenol, three diacetoxyscirpenols, three monoacetoxyscirpenol and scirrpenol, T-2 toxin and and related tricocethecenes, ${ }^{8}$ cytochalasin B, ${ }^{9}$ patulin, ${ }^{10}$ aflastatin $\mathrm{A},{ }^{11}$ 14-Hydromytoxin $\mathrm{B}$ and 16-Hydroxyroridin $\mathrm{E},{ }^{12}$ tenuazonic acid, ${ }^{13}$ 4-beta-acetoxyscirpendiol, ${ }^{14}$ gliotoxin, ${ }^{15}$ fluorinated pseurotin $\mathrm{A}$, synerazol, ${ }^{16}$ rubratoxin $\mathrm{B},{ }^{17}$ beauvericin ${ }^{18}$ showed antitumor activities in different types of cancer cell line and in vivo. Harri et al. reported that the trichothecenes verrucarins A and B and roridin A inhibited the growth of Ehrlich ascites tumor in mice and Walker carcinoma in rats. Myrocin C, a new diterpene from soil fungus Myrothecium verrucaria increases the life span of EAC-bearing mice. ${ }^{19}$ Leuteoskyrin, a hydroxyanthraquinone is proved to inhibit mRNA synthesis in Ehrlich ascites tumor cells. ${ }^{20,21}$ Oxidative stress may be involved in both initiation and promotion of multi-step carcinogenesis. Some synthetic, ${ }^{22}$ biogenic chemicals, ${ }^{23}$ nanoparticals, ${ }^{24}$ phytochemical ${ }^{25,26}$ can prevent oxidative $\operatorname{stress}^{22,23}$ and thus can modulate the expression of genes related to tumor promotion. 
Table I. Mean survival time and increased life span of EAC-bearing mice after the treatment of MT8I and acetic acid-MT8I

\begin{tabular}{|c|c|c|c|c|}
\hline Group & $\begin{array}{l}\text { EAC challenge cell } \\
\text { no./mouse }\end{array}$ & $\begin{array}{l}\text { Mean survival time } \\
\text { (days) Mean } \pm \text { SEM }\end{array}$ & $\begin{array}{l}\text { Increase in life } \\
\text { span (\%) }\end{array}$ & $\begin{array}{l}30 \text { days survivors/ } \\
\text { total no. }\end{array}$ \\
\hline Saline control $(0.9 \% \mathrm{NaCl} w / v)$ & - & - & - & $6 / 6$ \\
\hline $\begin{array}{c}\text { Vehicle control ( } 0.01 \mathrm{ml} \text { propylene glycol/20 gm } \\
\text { of body weight) }\end{array}$ & $2 \times 10^{6}$ & $16.0 \pm 1.75$ & $2.17^{\mathrm{a}}$ & $0 / 6$ \\
\hline MT8I low dose ( $5 \mathrm{mg} / \mathrm{kg}$ body weight) & $2 \times 10^{6}$ & $24.0 \pm 1.67^{*}$ & $50^{b}$ & $1 / 6$ \\
\hline Aa-MT8I low dose (8.93 mg/kg body weight) & $2 \times 10^{6}$ & $23.0 \pm 1.65^{*}$ & $43.75^{b}$ & $1 / 6$ \\
\hline Aa-MT8I high dose (II.48 mg/kg body weight) & $2 \times 10^{6}$ & $25.90 \pm 1.38^{*}$ & $61.88^{b}$ & $1 / 6$ \\
\hline 5 -Fluorouracil (20 mg/kg body weight) & $2 \times 10^{6}$ & $40.2 \pm 1.08^{*}$ & $151.25^{\mathrm{b}}$ & $5 / 6$ \\
\hline
\end{tabular}

Data given are Mean \pm SEM; $n=6$. "significant different at $p<0.05,{ }^{* *}$ significant different at $p<0.01$, ${ }^{* * *}$ significant different at $p<0.00$ I; EAC Control and Vehicle Control are compared to Saline control; Treated groups are compared to Vehicle Control by one-way ANOVA followed by Student's t-test.

Mycotoxin MT81 was isolated, purified and identified in our laboratory from a locally isolated fungal strain of Penicillium nigricans (patent no. 156916 dated 15.2.82, Govt. of India). MT81 is a dextrorotatory polyhydroxyanthraquinone compound having molecular formula of $\mathrm{C}_{22} \mathrm{H}_{18} \mathrm{O}_{7}$ and molecular wt. of $394 .{ }^{27}$ Its $\mathrm{LD}_{50}$ value is $35.1 \mathrm{mg} / \mathrm{Kg}$ body wt. in mice. MT81 is a good hyperglycemic, ${ }^{28}$ antimicrobial ${ }^{29}$ and antileishmanial ${ }^{30}$ agents. It produces massive bone marrow depression, ${ }^{31}$ liver, ${ }^{32}$ brain $^{33}$ and kidney ${ }^{34}$ dysfunction. MT81 exhibits central nervous system depressant action. ${ }^{35}$ MT81 has shown in vitro and in vivo antitumor activity against Ehrlich ascites tumor cells. ${ }^{36}$

To generate more potent and less toxic toxin, a structural analogue, acetic acid (Aa-MT81) MT81 was synthesized in our laboratory having $\mathrm{LD}_{50}$ value $80.4 \mathrm{mg} / \mathrm{kg}$ body weight in mice. This analogue was reported to possess antimicrobial ${ }^{29}$ and antileishmanial ${ }^{30}$ effects. The Ehrlich ascites tumor cell (EAC) is a spontaneous murine mammary adenocarcinoma ${ }^{1}$ and carried out in inbred mice by serial intraperitoneal (i.p.) administration. As (-)-luteoskyrin and (+)-rugulosin being hydroxyanthraquinone possess antitumor properties, present study was carried out to evaluate the antitumor and antioxidant activities of MT81 and its structural analogue (which are also polyhydroxyanthraquinone) against Ehrlich ascites carcinoma (EAC) in mice.

\section{Results}

Short-term (in vitro) cytotoxicity. The in vitro cytotoxicity of MT81 and its structural analogue towards EAC cells showed that the $\mathrm{IC}_{50}$ of MT81, Aa-MT81 were $17 \mu \mathrm{g}, 22 \mu \mathrm{g} / \mathrm{ml}$ respectively. The degree of in vitro lethality is slightly more in case of MT81 due to its toxicity.

Mean survival time (MST). In the EAC control group, the mean survival time was $16.0 \pm 1.75$ days, while it increased to 24.0 $\pm 1.67(3.88 \mathrm{mg} / \mathrm{kg}), 28.5(5 \mathrm{mg} / \mathrm{kg})$ days in the MT81-treated groups, $23.0 \pm 1.62(8.93 \mathrm{mg} / \mathrm{kg}), 25.9 \pm 1.38(11.48 \mathrm{mg} / \mathrm{kg})$ days in the Aa-MT81-treated groups respectively. These results are almost comparable to that for 5 -fluorouracil $(20 \mathrm{mg} / \mathrm{kg})$, the standard drug, for which the MST was $40.2 \pm 1.08$ days.
In vivo treatment of $\mathrm{MT} 81$ and AaMT81 inhibit growth of EAC cells. The result in Figures 1 and 2 indicates that control EAC-bearing mice (EAC and vehicle control groups) had a gradual increase in body weight of about 22 to $24 \mathrm{gm}$ in 21 days from the day zero. When compared to the body weight of control EAC-bearing mice on day 21, the body weight of the treated mice decreased significantly by about $50 \%$, indicating the effect of MT81 and Aa-MT81 in preventing the growth of Ehrlich ascites tumor cells. Inhibition of tumor growth in vivo expressed by the mean survival time and 30 days survivor has been summarized in Table 1. In case of EAC control, mean survival time is $15.66 \pm 1.667$ (all died by 20 days) whereas with high dose of (7 $\mathrm{mg} / \mathrm{kg}$ of body weight) of MT81, mean survival time is $28.5 \pm 1.138$ days indicating $89.1 \%$ increase in longevity (Table 1) of the treated group with respect to EAC control. Aa-MT81 have demonstrated enhanced effect on the mean life span by $59.3 \%$. The decrease in body weight in toxin-treated mice has been shown in Figures 1 and 2. The effects of MT81 and its structural analogue at different doses on tumor volume and viable tumor cell count are shown in Figures 4 and 5. MT81 and Aa-MT81 reduced the tumor volume, viable tumor cell count, packed cell volume (Fig. 11), and protein percent (Fig. 12).

Effect on normal peritoneal cells. The average number of peritoneal exudates cells in normal mice was found to be $5.3 \pm$ $0.248 \times 10^{6}$. Treatment of MT81 and its two derivatives increase the number of peritoneal cells significantly compared to the vehicle control group (Fig. 6).

Hematological parameters. Hematological parameters of EAC-bearing mice on day 14 were found to be significantly changed from normal (saline control) group (Table 2, Figs. 7-10). Hemoglobin content and RBC count in the EAC and vehicle control group were significantly $(\mathrm{p} \leq 0.01)$ decreased in comparison to the normal group. MT81 increased the hemoglobin content and RBC counts to a less extent whereas Aa-MT81 increased them significantly $(p<0.05)$. The total $\mathrm{WBC}$ counts and protein were found to be increased significantly in the vehicle control group ( $\mathrm{p}<0.01)$. Administration of MT81 and its structural analogue at the above said doses reduces the WBC counts and protein as compared to the vehicle control. 


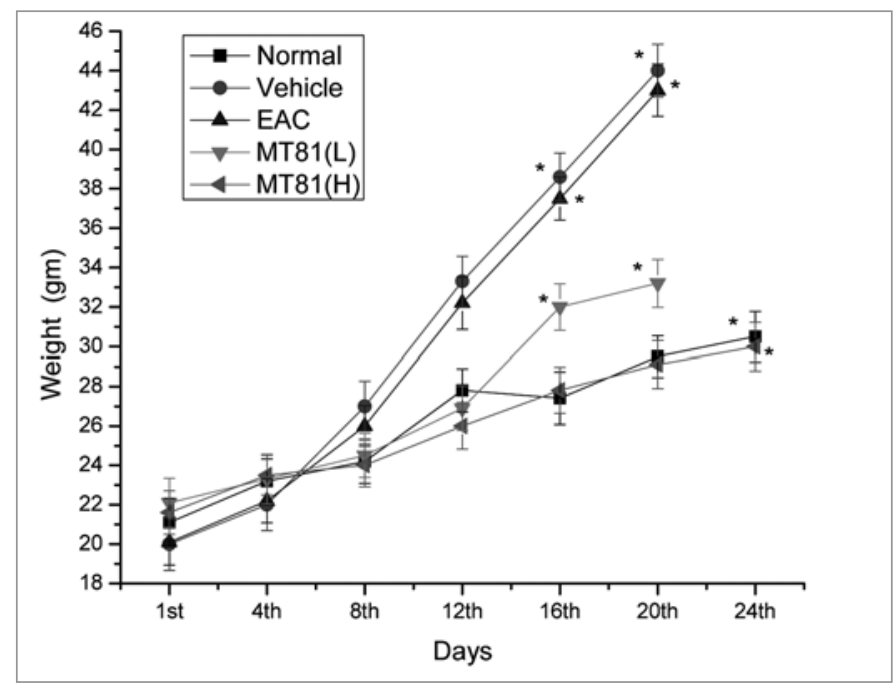

Figure I. Inhibitory role of MT8I on the body weight change in EAC bearing mice. Data given are Mean $\pm \mathrm{SEM} ; \mathrm{n}=6$. ${ }^{*}$ significant different at $\mathrm{p}<0.05$, **significant different at $\mathrm{p}<0.01$, ***significant different at $p<0.00$ I; EAC Control and Vehicle Control are compared to Saline control; Treated groups are compared to Vehicle Control by one-way ANOVA followed by Student's t-test.

There was a decrease in lymphocytes in malignancy, accompanied by an increase in neutrophils. The treatment changed those altered parameters significantly ( $\mathrm{p}<0.01$ ), to near normal in a dose-dependent manner.

Lipid peroxidation and glutathione content. As shown in Figure 14, the levels of lipid peroxidation in liver tissue were significantly increased in EAC and vehicle control group as compare to the normal group $(\mathrm{p}<0.01)$. After administration of MT81 and its Acetic acid analogue to EAC bearing mice the levels of lipid peroxidation were reduced respectively as compared to EAC and vehicle control. Inoculation with EAC drastically decreased the GSH content in vehicle control group in comparison to normal group. The administration of Aa-MT81 increased GSH level in a dose dependent manner compared to MT81 but not significantly.

Effect on antioxidant enzymes. The activities of superoxide dismutase and catalase in the livers of EAC bearing mice decreased in EAC and vehicle control groups $(\mathrm{p}<0.05)$. Treatment with MT81 and its structural analogue increased these enzyme activities to some extent but not in a significant manner (Figs. 16 and 17).

\section{Discussion}

The present study was carried out to evaluate the antitumor effect and antioxidant status of mycotoxin MT81 and its structural analogue in EAC-bearing mice. The treated animals significantly inhibited the tumor volume, packed cell volume, viable tumor cell count, increased the mean survival time, peritoneal cell count. They also restored the hematological parameters to more or less normal levels. They decreased the hepatic lipid peroxidation and increased the antioxidant enzyme SOD and CAT as well as the GSH level.

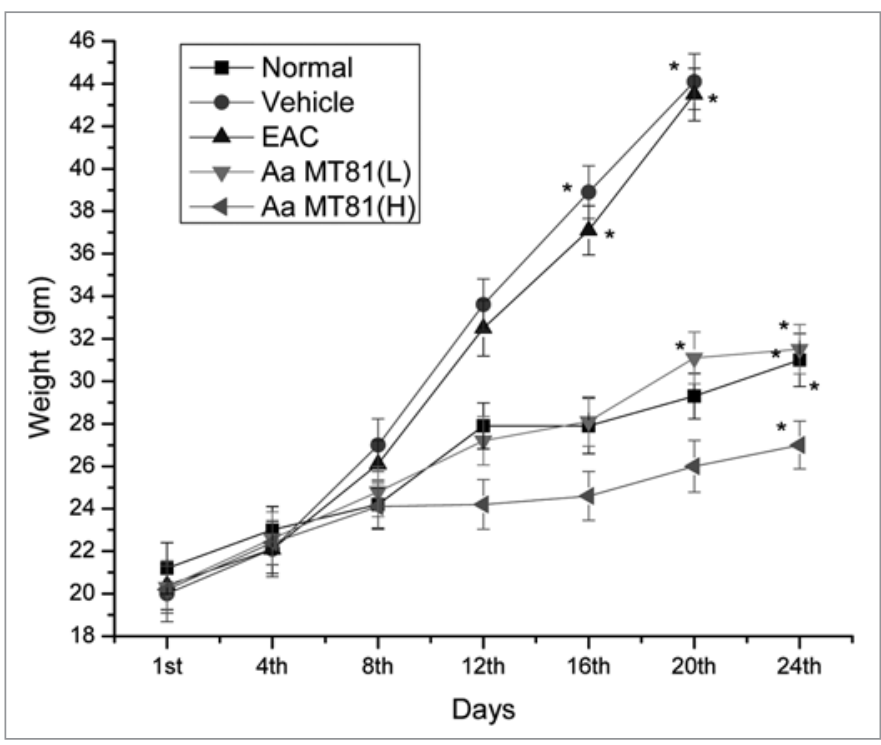

Figure 2. Inhibitory role of AaMT8I on the body weight change of EAC-bearing mice. Data given are Mean $\pm \mathrm{SEM} ; \mathrm{n}=6$. *significant different at $p<0.05$, **significant different at $p<0.01$, ***significant different at $p<0.001$; EAC Control and Vehicle Control are compared to Saline control; Treated groups are compared to Vehicle Control by one-way ANOVA followed by Student's t-test.

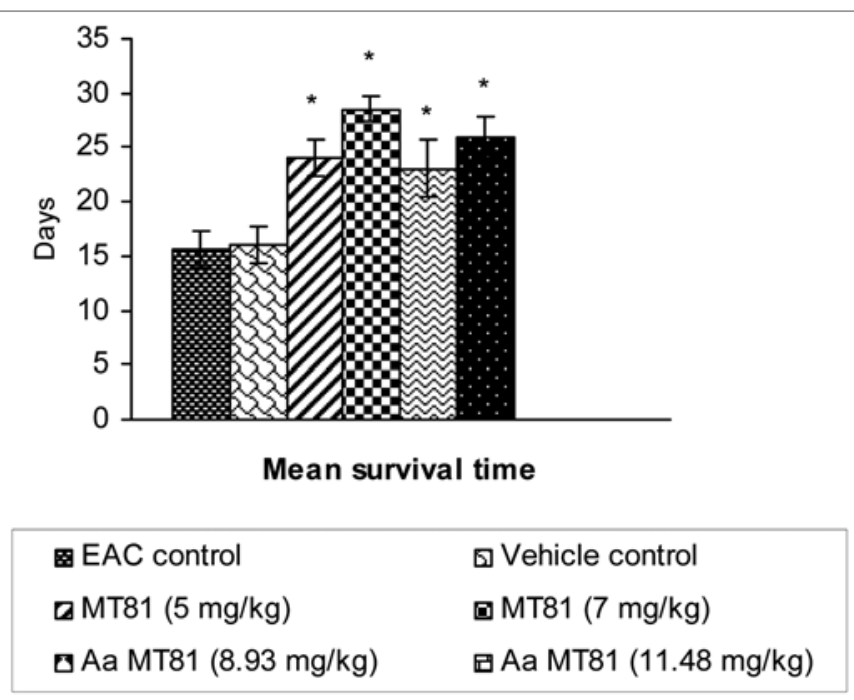

Figure 3. Modulatory role of MT8I and AaMT8I on Mean Survival Time of EAC-bearing mice. Data given are Mean \pm SEM; $n=6$. *significant different at $p<0.05$, **significant different at $p<0.0$, ***significant different at $p<0.001$; EAC Control and Vehicle Control are compared to Saline control; Treated groups are compared to Vehicle Control by one-way ANOVA followed by Student's t-test.

In EAC-bearing mice, a regular rapid increase in ascites tumor volume is seen. Ascites fluid is the direct nutritional source for tumor cell and so a rapid increase of this fluid is very necessary factor for tumor growth and nutrition. An anticancer drug is considered reliable if it can prolong the life span of animals. ${ }^{37}$ MT81 and its Acetic acid analogue decrease the ascites fluid volume, viable EAC cell count and increase the percentage of life span. 


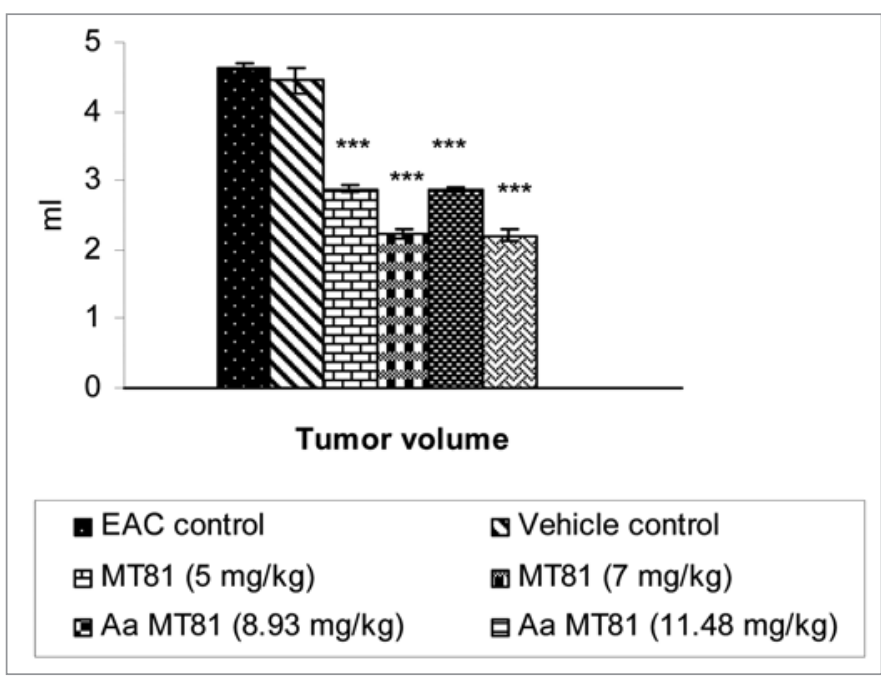

Figure 4. Inhibition of Tumor Volume of EAC-bearing mice by MT8I and $A a M T 8 I$. Data given are Mean \pm SEM; $n=6$. *significant different at $p<0.05$, **significant different at $p<0.01$, ***significant different at $p$ $<0.001$; oryEAC Control and Vehicle Control are compared to Saline control; Treated groups are compared to Vehicle Control by one-way ANOVA followed by Student's t-test.

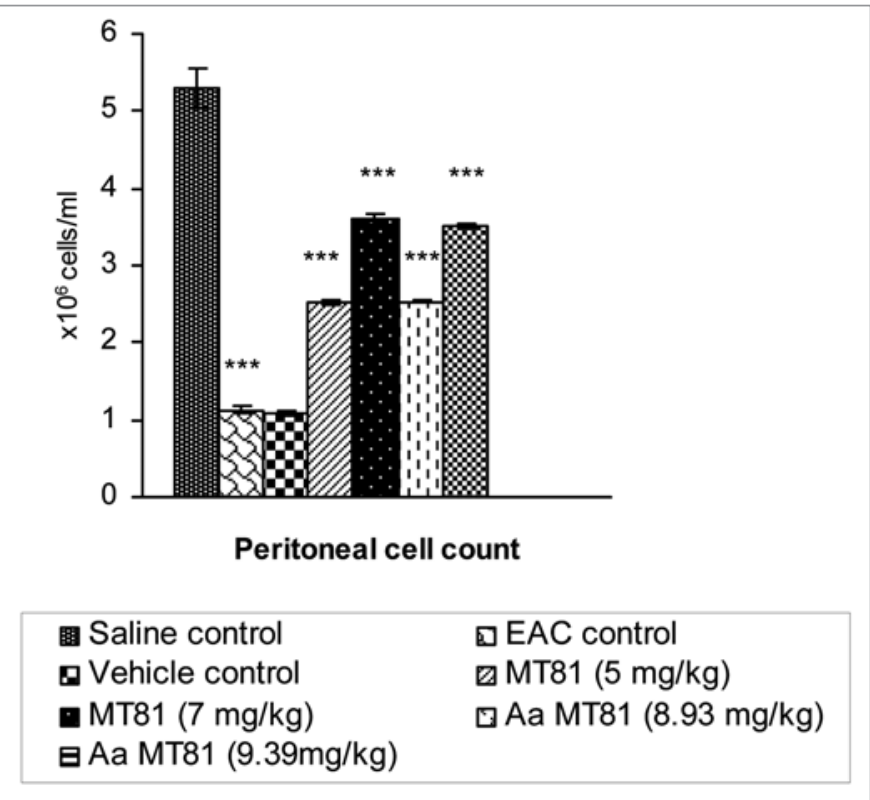

Figure 6. Increase of Peritoneal Cell Count of EAC-bearing mice by MT8I and AaMT8I on. Data given are Mean $\pm S E M ; n=6$. *significant different at $\mathrm{p}<0.05$, **significant different at $\mathrm{p}<0.01$, ***significant different at $p<0.001$; EAC Control and Vehicle Control are compared to Saline control; Treated groups are compared to Vehicle Control by one-way ANOVA followed by Student's t-test.

By decreasing the ascites fluid volume and arresting the tumor growth these toxins increase the life span of EAC bearing mice.

Myelosupression and anemia are the major outcome after cancer chemotherapy ${ }^{38}$ In tumor-bearing mice, anemia occurs due to the diminution in $\mathrm{RBC}$ or hemoglobin percentage, and these may happens either due to iron deficiency or due to hemolytic

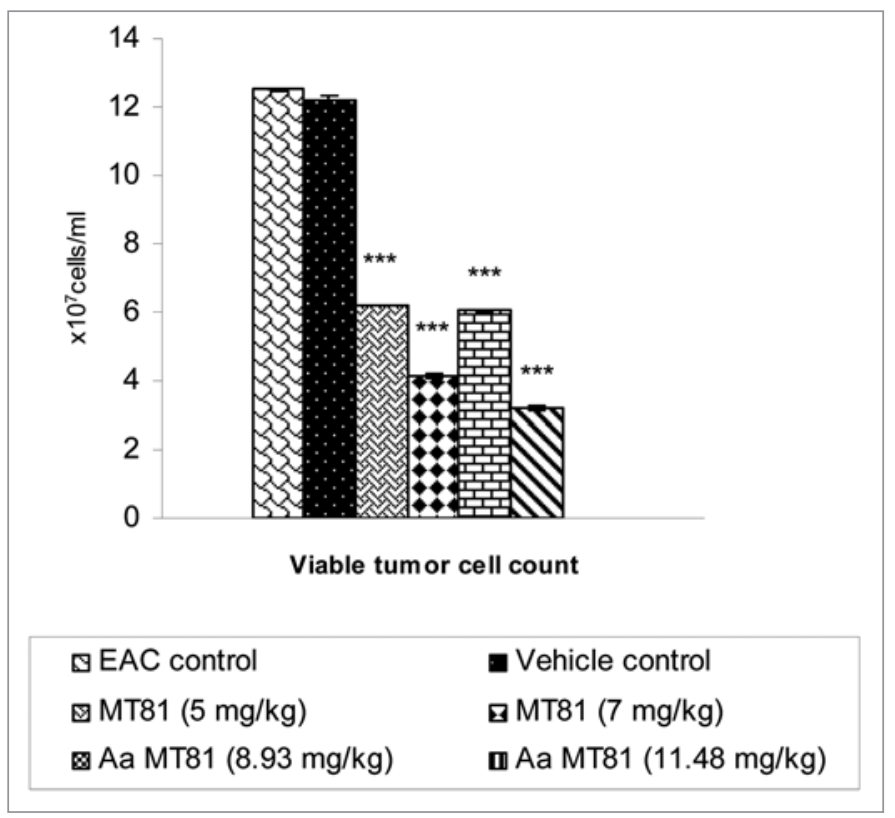

Figure 5. Inhibition of Viable Tumor Cell Count of EAC-bearing mice by MT8I and AaMT8I on Data given are Mean \pm SEM; $n=6$. *significant different at $p<0.05$, ** significant different at $p<0.01$, ***significant different at $p<0.00$ I; EAC Control and Vehicle Control are compared to Saline control; Treated groups are compared to Vehicle Control by one-way ANOVA followed by Student's t-test.

or myelopathic conditions. ${ }^{39}$ Administration of Acetic acid analogue by restoring hemoglobin content, $\mathrm{RBC}$ and $\mathrm{WBC}$ count towards normal exhibit its protective role on hemopoietic system compared to its parent toxin, MT81. The hematological parameter showed that hemoglobin content and total RBC count were found to be lower in case of EAC control group in comparison with saline control. Most of the cases of low doses of the toxins, the values are found to be less significant. But in case of high dose of Aa-MT81, significant increase in hemoglobin content and RBC count were observed but which were not seen in case of high dose of MT81, most probably due to its higher toxicity than Acetic acid analogue. The toxin treated animals showed comparatively lower total WBC count than EAC and vehicle control. It may be due to the tumorocidal activity of the toxins.

Cancer is considered as a multifactor disease, where oxidative stress may be involved in both initiation and promotion of multi-step carcinogenesis. Reactive oxygen species (ROS) can accelerate DNA damage, stimulate pro-carcinogenesis, initiate lipid peroxidation, inactivate antioxidant enzyme systems and thus can modulate the expression of genes related to tumor promotion. ${ }^{40,41}$

Excessive production of free radicals cause macromolecular damage and can induce lipid peroxidation in vivo. ${ }^{42}$ Malondialdehyde (MDA) the end product of lipid peroxidation, are seen to be higher in cancer tissues than in non-diseased organ. ${ }^{43} \mathrm{GSH}$, an important non-protein thiol, plays a significant role in protecting cells by scavenging $\mathrm{ROS}^{44}$ and potent inhibitor of the neoplastic process. Aa-MT81 significantly decreased the lipid peroxidation compared to MT81 by reducing the MDA 
Table 2. Modulatory role of MT8I and acetic acid-MT8I on the haematological parameters of EAC-bearing mice

\begin{tabular}{|c|c|c|c|}
\hline Group & Haemoglobin conc. (g\%) & Total RBC (x106/mm $\left.\mathrm{m}^{3}\right)$ & Total WBC $\left(\times 10^{3} / \mathrm{mm}^{3}\right)$ \\
\hline Saline control $(0.9 \% \mathrm{NaCl} w / v)$ & $8.9 \pm 0.19$ & $2.9 \pm 0.12$ & $7.6 \pm 0.15$ \\
\hline EAC control & $6.8 \pm 0.20$ & $1.9 \pm 0.07$ & $8.6 \pm 0.17$ \\
\hline $\begin{array}{c}\text { Vehicle control ( } 0.01 \mathrm{ml} \text { propylene glycol/20 gm } \\
\text { of body weight) }\end{array}$ & $7.0 \pm 0.12$ & $2.0 \pm 0.15$ & $8.5 \pm 0.15$ \\
\hline MT8I low dose (5 mg/kg body weight) & $7.3 \pm 0.24$ & $2.2 \pm 0.12$ & $8.2 \pm 0.19$ \\
\hline MT8I high dose (7 mg/kg body weight) & $7.4 \pm 0.11$ & $2.3 \pm 0.12$ & $8.09 \pm 0.11^{*}$ \\
\hline Aa-MT8I low dose ( $8.93 \mathrm{mg} / \mathrm{kg}$ body weight) & $7.4 \pm 0.31$ & $2.4 \pm 0.07$ & $8.4 \pm 0.10$ \\
\hline Aa-MT8I high dose (II.48 mg/kg body weight) & $7.75 \pm 0.21^{*}$ & $2.5 \pm 0.04^{*}$ & $8.19 \pm 0.17^{* *}$ \\
\hline
\end{tabular}

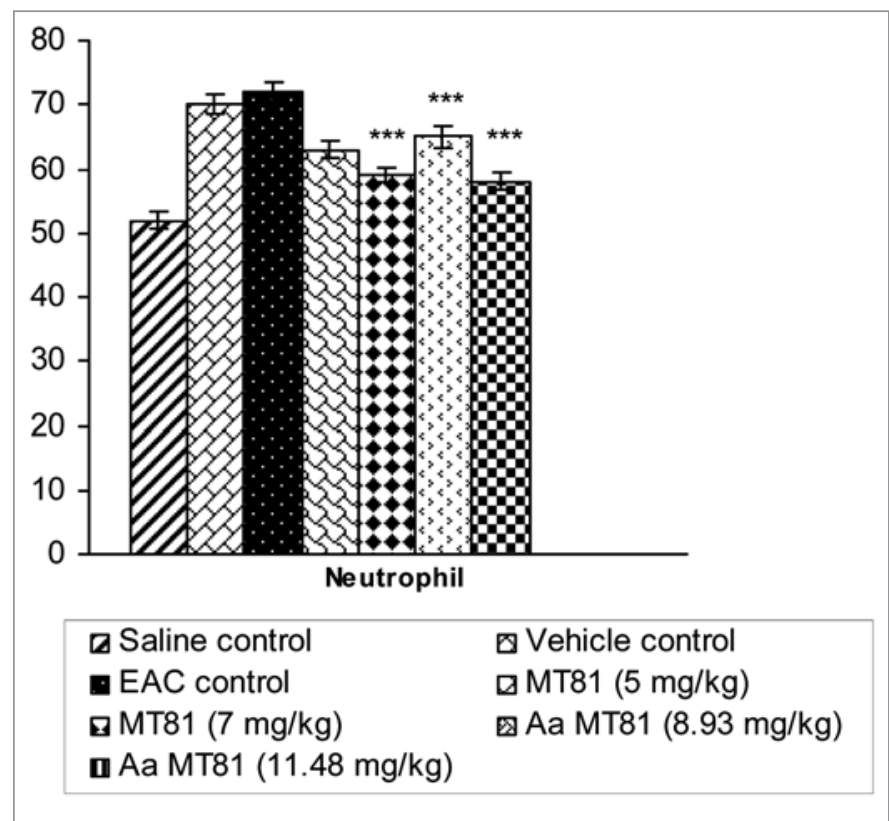

Figure 7. Modulatory role of MT8I, AaMT8I on Neutrophil Count of EAC-bearing mice. Data given are Mean $\pm \mathrm{SEM} ; n=6$. *significant different at $\mathrm{p}<0.05$, **significant different at $\mathrm{p}<0.01$, ***significant different at $\mathrm{p}<0.00 \mathrm{I}$; EAC Control and Vehicle Control are compared to Saline control; Treated groups are compared to Vehicle Control by one-way ANOVA followed by Student's t-test.

level but the glutathione content is not increased significantly in a dose-dependent manner most probably due to their toxicity.

SOD and CAT, the antioxidant enzymes prevent $\mathrm{H}_{2} \mathrm{O}_{2}-$ mediated intracellular damage, which is thought to be prerequisite for carcinogenesis. ${ }^{45}$ SOD dismutates superoxide anions $\left(\mathrm{O}_{2}^{-}\right)$to $\mathrm{H}_{2} \mathrm{O}_{2}$ and protects the cells against $\left(\mathrm{O}_{2}^{-}\right)$-mediated lipid peroxidation. CAT acts on $\mathrm{H}_{2} \mathrm{O}_{2}$ by decomposing it, thereby neutralizing its toxicity. Gupta et al. demonsrated that reduction in several antioxidant defense mechanisms correlates with the emergence of the malignant phenotype. ${ }^{46}$ Consistent with this, a diminution in SOD activity in EAC-bearing mice may be due to the loss of $\mathrm{Mn}^{2+}$-containing SOD activity in EAC cells and loss of mitochondria, leading to a decrease in total SOD activity in the liver. ${ }^{47} \mathrm{~A}$ small amount of catalase in tumor cells was reported. ${ }^{48}$

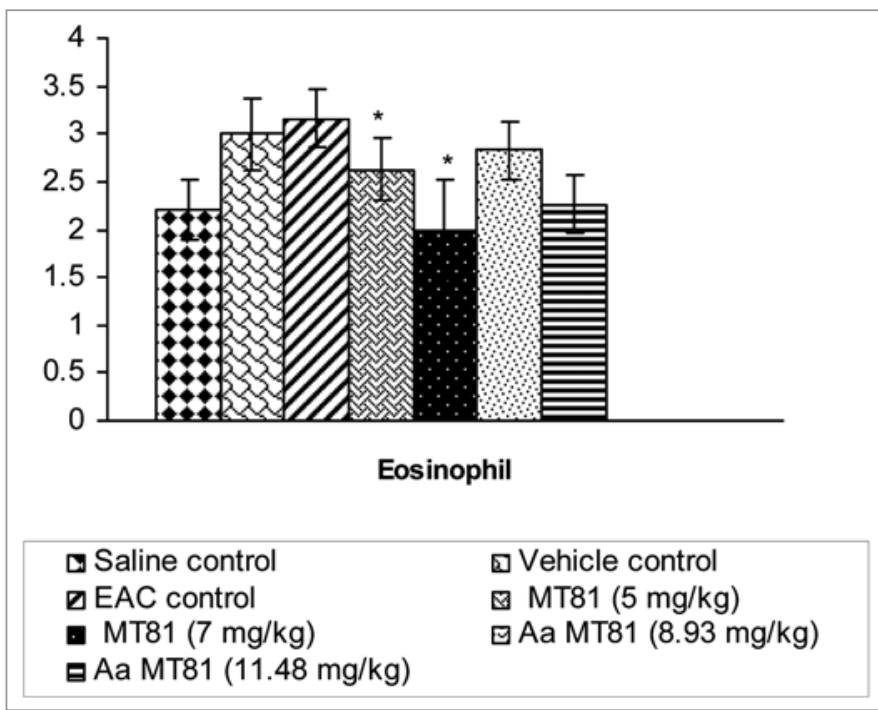

Figure 8. Modulatory role of MT8I, AaMT8I on Eosinophil Count of EAC-bearing mice. Data given are Mean \pm SEM; $n=6$. *significant different at $\mathrm{p}<0.05$, **significant different at $\mathrm{p}<0.01$, ***significant different at $p<0.00$ I; EAC Control and Vehicle Control are compared to Saline control; Treated groups are compared to Vehicle Control by one-way ANOVA followed by Student's t-test.

The inhibitions of SOD and CAT to some extent activities as a result of tumor growth were reported. ${ }^{49}$ Similar findings were observed in the present study with EAC-bearing mice. The treatment of MT81 and Aa-MT81 at different doses increased the SOD and CAT levels to some extent in a dose-dependent manner like the chemopreventive efficacy of perillyl alcohol probably due to the inhibition of oxidative stress responses ${ }^{50}$ and the structural analogue showed more potentiality.

The in vitro cytotoxicity and the significant inhibition of in vivo growth of EAC cells, increase in life span and of the tumorbearing mice confirm the antitumorogenic effect of MT81 and its acetic acid derivative against EAC cells (Fig. 17).

Being less toxic than parent toxin MT81, the Acetic acid analogue showed more prominent antineoplastic activities against EAC cells compared to MT81. At the same time both exhibit mild antioxidant potential for the EAC bearing mice in spite of their different toxic side effects. 


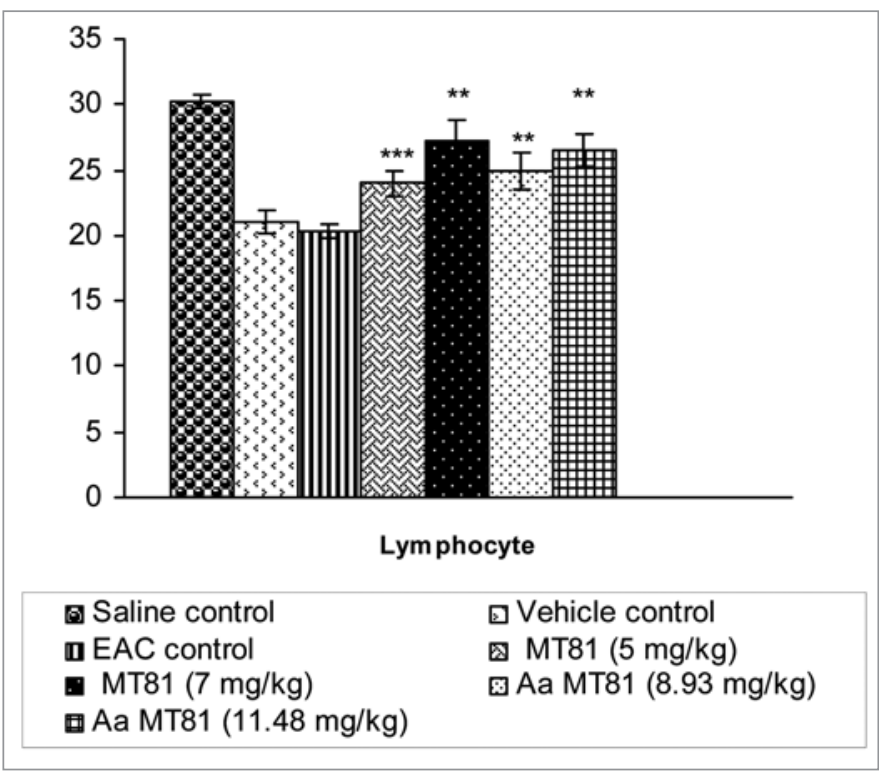

Figure 9. Modulatory role of MT8I, AaMT8I on Lymphocyte Count of EAC-bearing mice. Data given are Mean \pm SEM; $n=6$. *significant different at $p<0.05, * *$ significant different at $p<0.01$, ***significant different at $p<0.00$ I; EAC Control and Vehicle Control are compared to Saline control; Treated groups are compared to Vehicle Control by one-way ANOVA followed by Student's t-test.

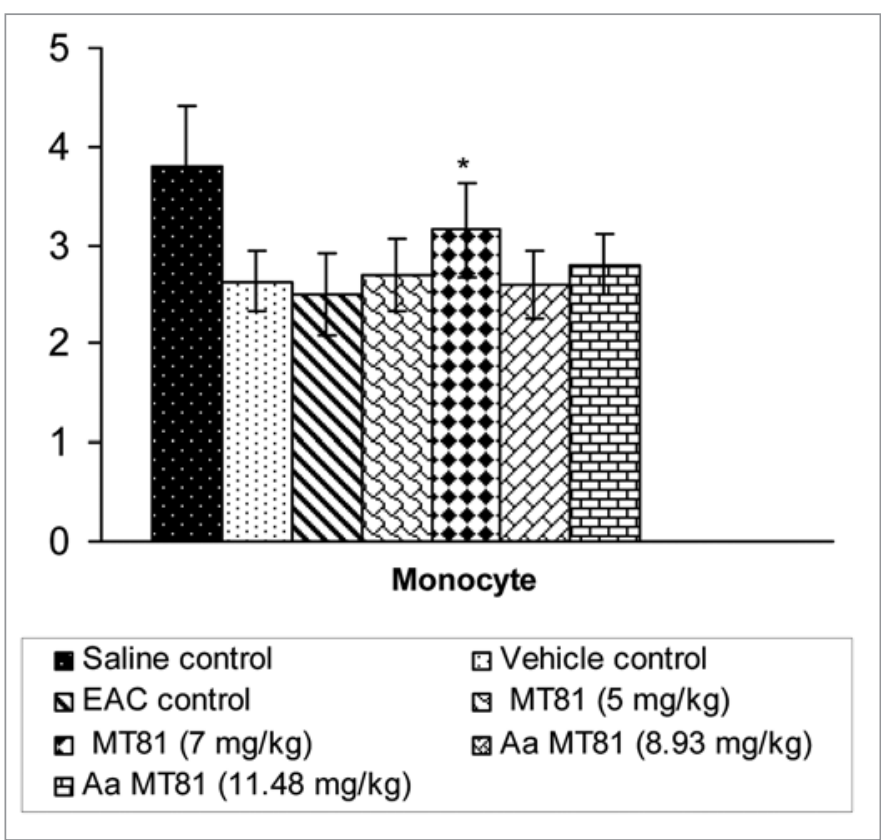

Figure 10. Modulatory role of MT8I, AaMT8I on Monocyte Count of EAC-bearing mice. Data given are Mean \pm SEM; $n=6$. *significant different at $\mathrm{p}<0.05, * *$ significant different at $\mathrm{p}<0.01$, $* * *$ significant different at $\mathrm{p}<0.00 \mathrm{I}$; EAC Control and Vehicle Control are compared to Saline control; Treated groups are compared to Vehicle Control by one-way ANOVA followed by Student's t-test.

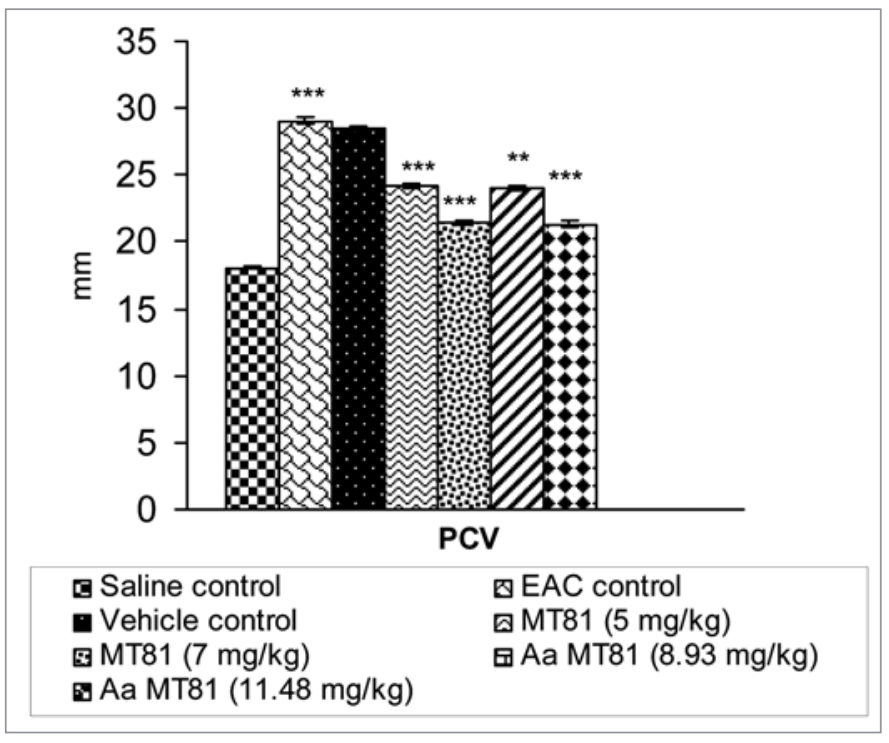

Figure II. Role of MT8I, AaMT8I on Packed Cell Volume (PCV) of EAC-bearing mice. Data given are Mean $\pm S E M ; n=6$. *significant different at $p<0.05$, **significant different at $p<0.01$, ***significant different at $\mathrm{p}<0.00$ I; EAC Control and Vehicle Control are compared to Saline control; Treated groups are compared to Vehicle Control by one-way ANOVA followed by Student's t-test.

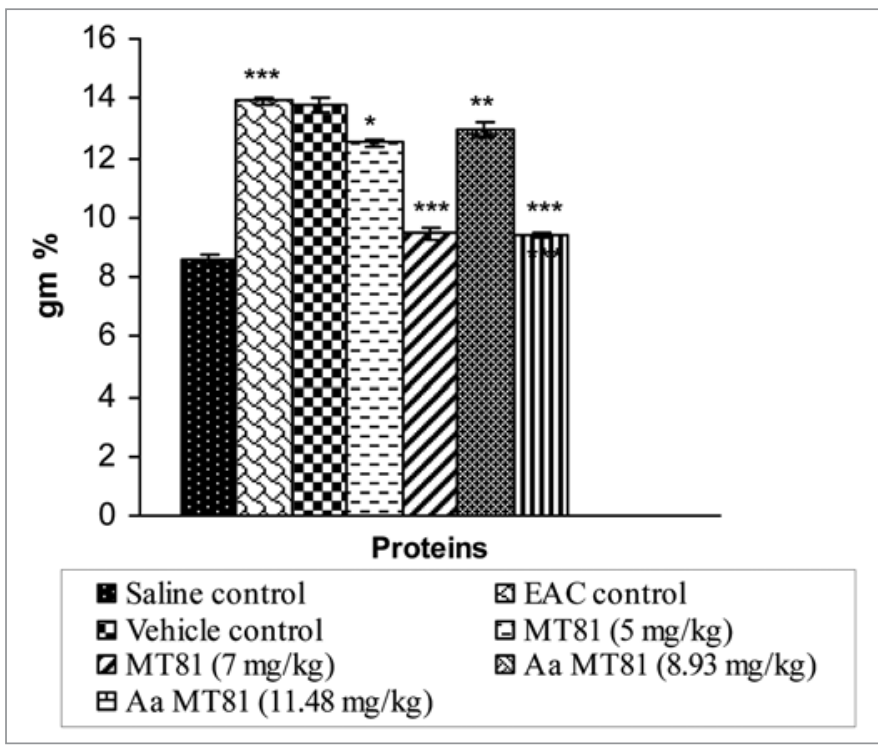

Figure 12. Role of MT8I, AaMT8I on Proteins\% of EAC-bearing mice. Data given are Mean \pm SEM; $n=6$. *significant different at $p<0.05$, $* *$ significant different at $p<0.0$ I, ***significant different at $p<0.00$ I; EAC Control and Vehicle Control are compared to Saline control; Treated groups are compared to Vehicle Control by one-way ANOVA followed by Student's t-test. 


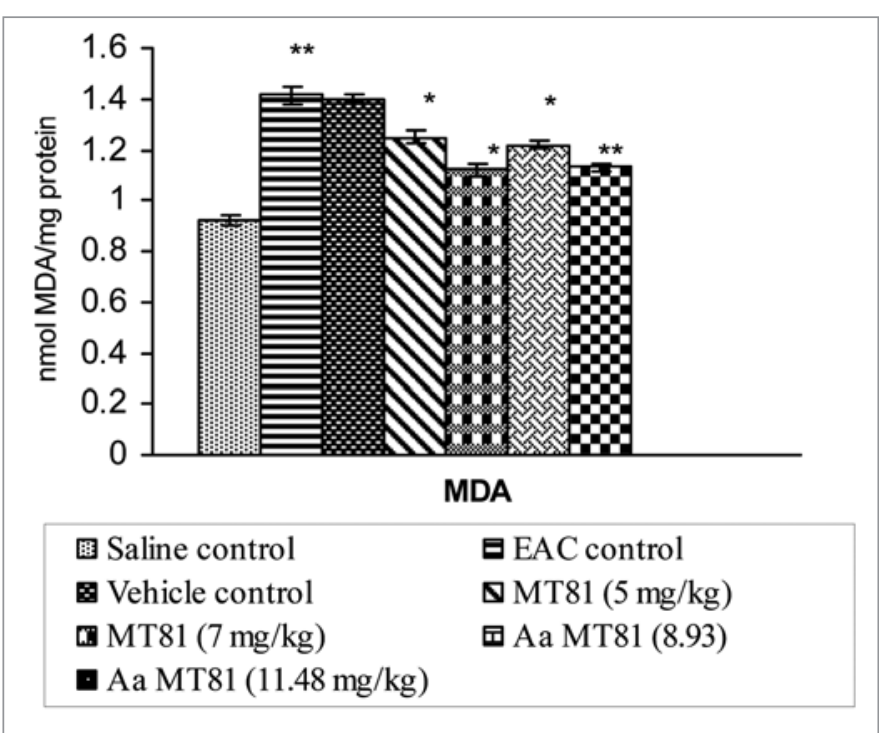

Figure 13. MDA content of EAC-bearing mice after the treatment of MT8I and AaMT8I. Data given are Mean \pm SEM; $n=6$. *significant different at $\mathrm{p}<0.05$, **significant different at $\mathrm{p}<0.01$, ***significant different at $p<0.001$; EAC Control and Vehicle Control are compared to Saline control; Treated groups are compared to Vehicle Control by one-way ANOVA followed by Student's t-test.

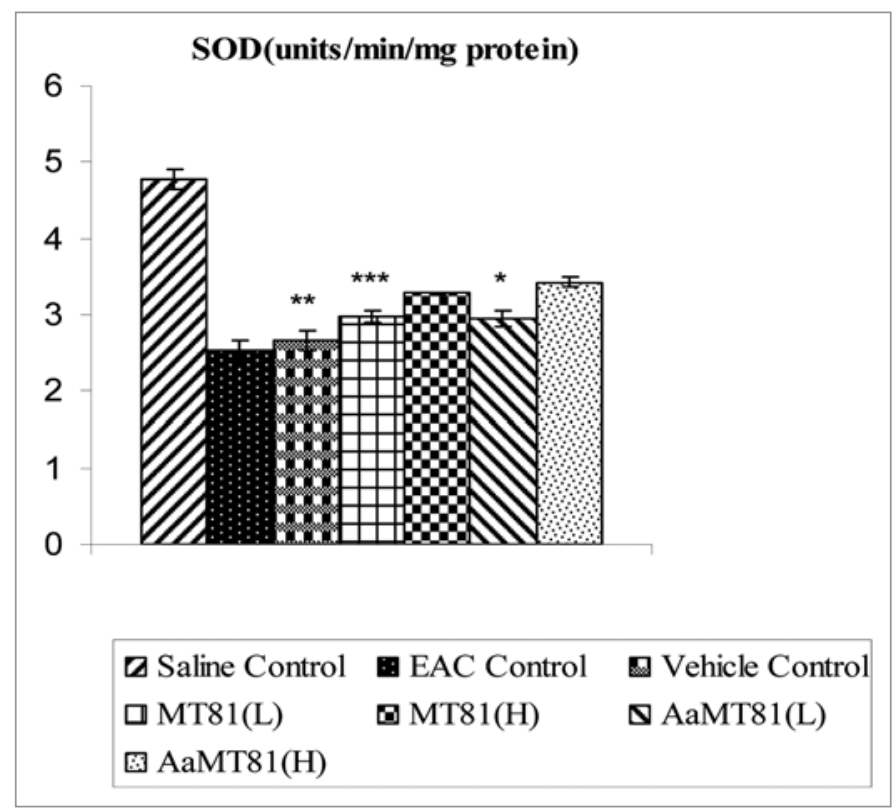

Figure 15. SOD activity of EAC-bearing mice after the treatment of MT8I and AaMT8I. Data given are Mean \pm SEM; $n=6$. *significant different at $p<0.05$, ** significant different at $p<0.01$, ***significant different at $\mathrm{p}<0.00 \mathrm{I}$; EAC Control and Vehicle Control are compared to Saline control; Treated groups are compared to Vehicle Control by one-way ANOVA followed by Student's t-test.

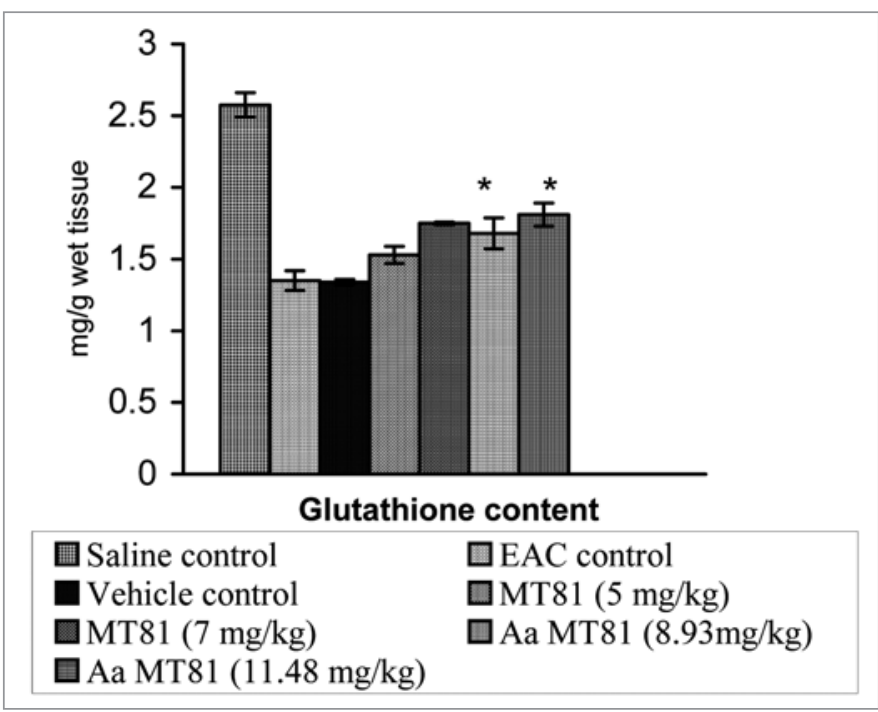

Figure 14. Glutathione content of EAC-bearing mice after the treatment of MT8I and AaMT8I. Data given are Mean \pm SEM; $n=6$. *significant different at $p<0.05$, **significant different at $p<0.01$, ***significant different at $p<0.001$; EAC Control and Vehicle Control are compared to Saline control; Treated groups are compared to Vehicle Control by one-way ANOVA followed by Student's t-test.

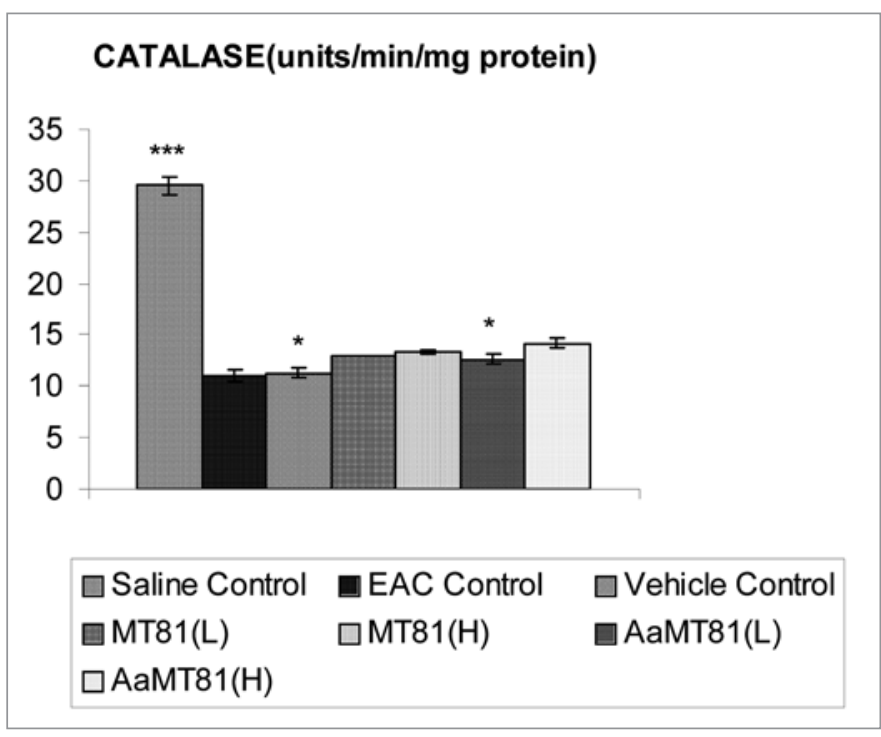

Figure 16. Catalase activity of EAC-bearing mice after the treatment of MT8I and AaMT8I. Data given are Mean \pm SEM; $n=6$. *significant different at $p<0.05$, **significant different at $p<0.01$, ***significant different at $p<0.001$; EAC Control and Vehicle Control are compared to Saline control; Treated groups are compared to Vehicle Control by one-way ANOVA followed by Student's t-test. 


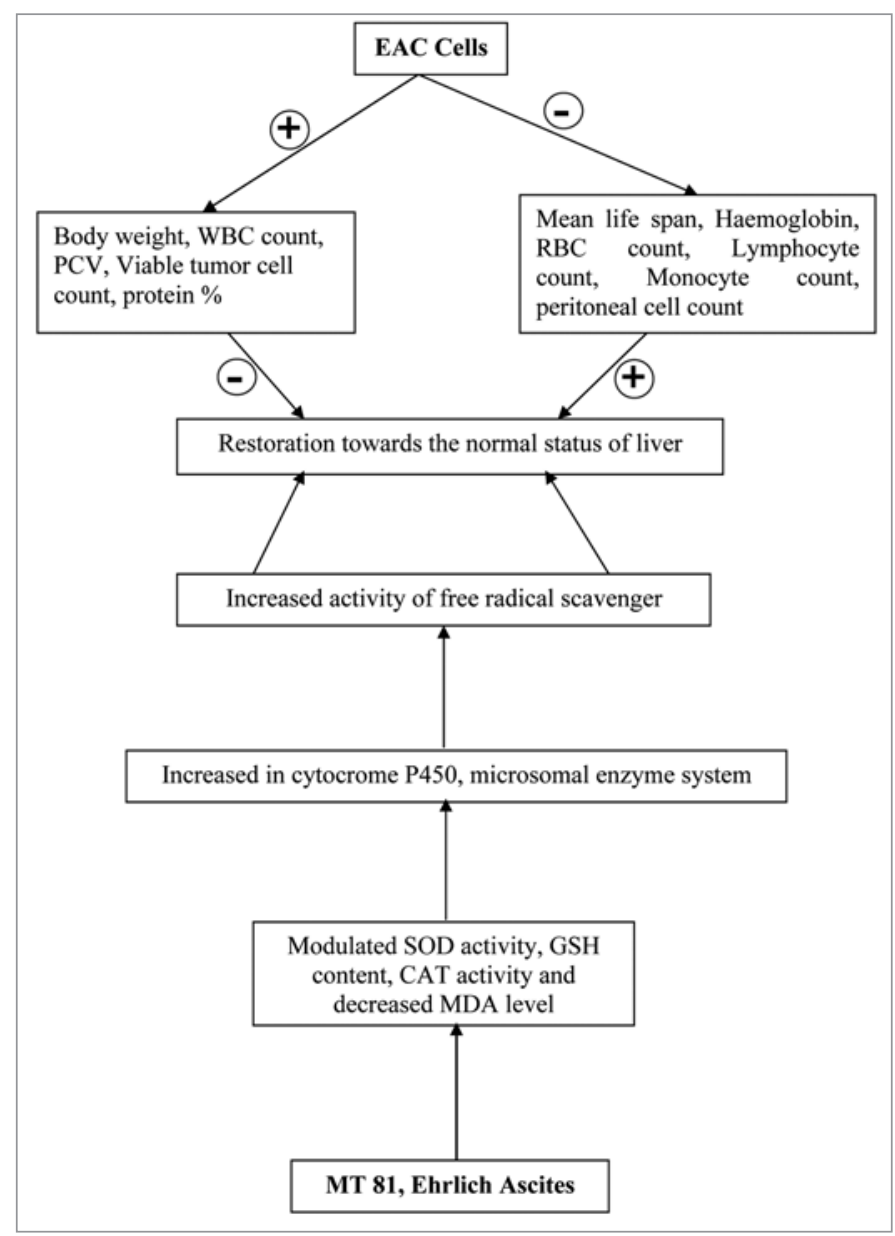

Figure 17. Possible potential anti-neoplastic cellular pathways of MT8I and AaMT8I on EAC-bearing mice. Where '+' denoted to stimulatory and '-' denoted to inhibitory effects to the respective parameters.

\section{Materials and Methods}

Chemicals and reagents. All fine chemicals were obtained from Sigma Chemical, USA. Other chemicals used were analytical grade and obtained locally.

Animals. Malealbino(Swiss) miceweighing between 18-25g were used throughout the study. The mice were obtained from the animal house of Jadavpur University, Kolkata and grouped and housed in polyacrylic cages $(38 \times 23 \times 10 \mathrm{~cm})$ with not more than twelve animals per cage. They were maintained in a constant room temperature of $28-30^{\circ} \mathrm{C}$ and $55-65 \%$ humidity and a controlled day length, 14 hours light and 10 hours dark cycle. Standard pellet diet containing $66 \%$ starch, $20 \%$ casein, $8 \%$ fat, $2 \%$ standard vitamins and $4 \%$ salt was collected from Hindustan Lever Co., Ltd., (India) and given to the animals. Water was given ad libitum. The mice were acclimatized to laboratory conditions for 10 days before commencement of the experiment. All procedures described were reviewed and approved by the University animals Ethical Committee.

Ehrlich's ascites carcinoma (EAC) cells and its transplantation. EAC cells were obtained by the courtesy of Indian Institute of Chemical Biology and were maintained by weekly intraperitoneal transplantation in the abovesaid mice at the concentration of $2 \times 10^{6} / \mathrm{cell} s /$ mouse. The EAC cells were harvested after 7-10 days. The washed cells free of contaminating RBC were taken in $0.14 \mathrm{M} \mathrm{NaCl}$ solutions. Cells were found to be $99 \%$ viable by the trypan blue exclusion assay.

Study of in vitro cytotoxicity. Washed and viable EAC cells of 7-10 days old tumor were suspended into isotonic solution (Phosphate buffer saline) and were adjusted to $1 \times 10^{6}$ cells $/ \mathrm{ml}$. In a series of test tubes $1 \mathrm{ml}$ of this suspension was taken and $0.01 \mathrm{ml}$ of varying concentrations ( 5 to $25 \mu \mathrm{g}$ ) of MT81 and Aa-MT81 were added. One tube was kept as EAC control and in another tube marked as vehicle control, $0.01 \mathrm{ml}$ of propylene glycol was added. The tubes were mildly shaken to mix the contents and incubated at $37^{\circ} \mathrm{C}$ for $3 \mathrm{hr}$ under a $\mathrm{CO}_{2}$ atmosphere. After 3 hours, percentage of viability of EAC cells was determined by trypan blue exclusion method. ${ }^{51}$

Assessment of in vivo antitumor activity. Male albino mice were divided into nine groups each group containing twelve. Washed and viable EAC cells were resuspended in normal saline and inoculated $\left(0.2 \mathrm{ml}\right.$ of $2 \times 10^{6}$ cells $/$ mouse $)$ to animals of all groups intraperitoneally except the normal group. After $24 \mathrm{hrs}$, $5 \mathrm{ml} / \mathrm{kg} /$ day of normal saline were administered in Group 1 (Normal) and Group 2 (EAC control) and propylene glycol was administered in Group 3 (vehicle control group). MT81 (5 and $7.00 \mathrm{mg} / \mathrm{kg} /$ day), Aa-MT81 (8.93 and $11.48 \mathrm{mg} / \mathrm{kg}$ day) and the standard drug 5 -fluorouracil ${ }^{52}(20 \mathrm{mg} / \mathrm{kg})$ were administered intraperitoneally in Groups 4, 5, 6, 7, 8, respectively for subsequent 7 days. After the last dose and $18 \mathrm{hr}$ fasting, six mice from each group were sacrificed for the study of antitumor and antioxidant activities and hematological parameters. The rest of the animals of all groups were kept for study of the tumor growth response and host survival.

Determination of tumor growth response and host survival. Tumor growth was monitored by daily weight change and the survival time of host mouse by recording the mortality daily for 6 weeks and \% ILS was calculated, Using the following equations ${ }^{53,54}$

MST $=($ Day of first death + Day of last death $) / 2$

ILS $(\%)=[($ Mean survival time of treated group/mean survival time of control group) - 1] x 100

The antitumor activity of MT81 and its structural analogues were determined by change in ascites tumor volume, viable and nonviable tumor cell count, mean survival time (MST), and percentage-increased life span (\% ILS).

Study on normal peritoneal cells..$^{55}$ Peritoneal exudate cells were collected after the abovementioned treatment schedule by repeated intraperitoneal wash with normal saline and counted in each of the treated groups and compared with the saline and vehicle control group.

Study of haematological parameters. Total red blood cell (RBC), white blood cell (WBC) counts and haemoglobin content were measured from freely flowing tail vein 
blood. ${ }^{5,57}$ Differential leucocyte count of WBC was done from Leishman-stained blood smears ${ }^{58}$ of normal, EAC control, MT81, Aa-MT81-treated groups, respectively.

Antioxidant parameters. After the collection of blood samples, the mice were sacrificed. The liver of the mice were then excised, rinsed in ice-cold normal saline followed by cold $0.15 \mathrm{M}$ Tris- $\mathrm{HCl}$ ( $\mathrm{pH} 7.4$ ), blotted dry, and weighed. A $10 \%$ $\mathrm{w} / \mathrm{v}$ homogenate was prepared in $0.15 \mathrm{M}$ Tris- $\mathrm{HCl}$ buffer; a portion was utilized for the estimation of malondialdehyde ${ }^{59}$ and a second portion, after precipitating proteins with trichloroacetic acid, was used for the estimation of glutathione (GSH). ${ }^{60}$ The rest of the homogenate was centrifused at $1,500 \mathrm{rpm}$ for
$15 \mathrm{~min}$ at $4^{\circ} \mathrm{C}$. The supernatant thus obtained was used for the estimation of superoxide dismutase, catalase and protein. ${ }^{61-63}$

Statistical analyses. The experimental results were expressed as the mean \pm SEM. The data were statistically analyzed by oneway ANOVA followed by Student's t-test when EAC Control and Vehicle Control are compared to Saline control; Treated groups are compared to Vehicle Control. p $<0.05$, p $<0.01$, p $<$ 0.001 was considered significant.

\section{Acknowledgements}

We thank ICMR, New Delhi, India for providing financial support.

\section{References}

1. Peto J. Cancer epidemiology in the last century and the next decade. Nature 2001; 411:390-5.

2. Pankin DM, Bray F, Ferlay J, Pisani P. Global cancer statistico (2002) CA cancer. J Clin 2005; 55:74-108.

3. Williams RH, Lively DH, Delong DC, Cline JC, Sweeney MJ, Poore GA, Larsan SM. J Antibiot 1968; 21:463

4. Phillips TD, Chan PK, Hayes AW. Biochem Pharmacol 1980; 29:19.

5. Essery JM, O' Herron FA, Mc Gregor DN, Bradner WT. Preparation and antitumor activities of some derivatives of 5-methoxysterigmatocystin. J Med chem 1976; 19:1339-42.

6. Claridge CA, Schmitz H, Bradner WT. Antitumor activity of some microbial and chemical transformation products of anguidine (4,15-diacetoxyscirpene-3-ol). Cancer Chemotherapy Pharmacol 1979; 2:181-2.

7. Kameko T, Schmitz H, Essery JM, Rose W, Howell HG, O' Herron FA, et al. Struchural modification of anguidin and antitumor activities of its analognes. $\mathrm{J}$ Med Chem 1982; 25:579-89.

8. RAmu A, Yagen B, Ramu N. The cytotozicity of T-2 toxin and related 12,13-epoxytrichothecenes to Adriamycin-Sensitive and -resistant P388 teukemia cells. Cancer Chemotherapy Pharmacol 1989; 24:2647.

9. Bousquet PF, Panlsen LA, Fonday C, Lipski KM, Loncy KJ, Fon TP. Effect of cytochasim B in culture and in vivo on murine Madison 109 Luns carcinoma and on B16 melanoma. Cancer Res 1990; 50:1431-9.

10. Sigle-Murandi F, Steiman R, Krivobok S, Beriel H, Benoit-Guyod JL. Antitumor activity of patrtin and structural analogs. Pharmazie 1992; 47:288-91.

11. Ono M, Saknda S, Suzuki A, Isogai A. Aflastatin A, a novel irhibitor of aflatoxin production by aflatoxigenic fungi. J Antibiot (Tokyo) 1997; 50:111-8.

12. Alvi KA, Rabenstein J, Woodard J, Banker DD, Berghold JD, Lynch J, et al. 14'-Hydroxymytoxin B and 1 hydroxyroridin E, two new cytotoxic trichothecenes from Myrothecinm roridum. J Nat Prod 2002; 65:742-4

13. Antony M, Shukla Y, Janardhanan KK. Protection effect of tenuazonic acid against dimethye benz (a) antracene-induced skin carcinogenesis in mice. Teratog carcinog Mutogen 2002; 22:309-14.

14. Han HC, Lindequist U, Hyun JW, Kim YH, An HS, Lee DH, Kim HW. Apoptosis induction by 4beta-acetoxyscirpendiol from paecilomyces tenuipes in human leukaemia cell lines. Pharmazie 2004; 59:42-9.

15. Vigushim DM, Mirsaidi N, Broke G, Sun C, Pace P, Imuan L, et al. Gliotoxin is a dual inhibitor of farnesyl and geranyltransferase I with antitumor activity against Breast cancer in vivo. Med Orcol 2004; 21:21-30.

16. Igarashi Y, Tabuta y, Sekine A, Fujii K, Harada K, Oikawa T, et al. directed biosynthesis of fluorinated pseurotim A, Synerazol and gliotoxin. J Antibiot 2004; 57:748-54.

17. Fimtani V, Richetti A. chemotherapy 1993; 39:59.
18. Jow C, Chou B, Chen J. Tsai Beauvericin induces cytotoxic effects in human acute lymphoblastic leukemia cells through cytochrome release, caspase 3 activation: the causative role of calcium. Cancer Letters 216:65 173.

19. Masahira N, Hsuy H, Hirota A, Shimas, Nakayama M. J Antibioties 1989; 42:218.

20. Veno Y, Veno I, Ito K, Tatsuno T. Experientia 1967; 23:1001.

21. Veno Y, Veno I, Sato N, Iitoi Y, Saito M, Enomoto M, Tsunoda H. Jap J Exp Med 1971; 41:177.

22. Chaudhary SC, Alam MS, Siddiqui MS, Athar M Perillyl alcohol attenuates Ras-ERK signaling to inhibit murine skin inflammation and tumorigenesis. Chem Biol Interact 2009; 179:145-53.

23. Ardelt B, Juan G, Burfeind P, Salomon T, Wu JM, Hsieh TC, et al. An anti-tumor ribonuclease suppresses intracellular oxidative stress. Int J Oncol 2007; 31:663-

24. Yin JJ, Lao F, Meng J, Fu PP, Zhao Y, Xing G, Gao $\mathrm{X}$. Inhibition of tumor growth by endohedral metallofullerenol nanoparticles optimized as reactive oxygen species scavenger. Mol Pharmacol 2008; 74:1132-40.

25. Lee JH, Lee HJ, Lee HJ, Choi WC, Yoon SW, Ko SG. Rhus verniciflua Stokes prevents cisplatin-induced cytotoxicity and reactive oxygen species production in MDCK-I renal cells and intact mice. Phytomedicine 2009; 16:188-97.

26. Cebovi T, Spasi S, Popovi M. Cytotoxic effects of the Viscum album L. extract on Ehrlich tumour cells in vivo. Phytother Res 2008; 22:1097-103.

27. Gupta M, Chatterjee T, Sengupta S, Majumder SK. Structure of a new mycotoxin (MT81). Indian J Chem 1984; 13:393.

28. Gupta M, Dey SN, Dolui AK, Mukherjee S, Basu SK, Batabyal SK. Some enzymes and substrates of EmbdenMeyerhof pathway of different tissues and related hormones of mycotoxin, MT81 treated mice. Indian J Exp Biol 1988; 26:315-22.

29. Choudhury S, Rana MP, Chatterjee TK, Mazumder UK, Gupta M. Antimicrobial activities of mycotoxin MT81 and its structural derivatives. Indian J Exp Biol 1992; 30:140.

30. Majumder UK, Gupta M, Chowdhury S, Saha A. Antileishmanial activities of mycotoxin MT81 and its derivatives. Indian J Exp Biol 1993; 31:888-90.

31. Chatterjee T. Haematological changes produced in mice by a new mycotoxin (MT81).III World Conference on Clinical Pharmacology and Therapeutics, Stockholm 1986.

32. Gupta M, Chatterjee T, Dey SN, Mazumder SK. Effect of a new mycotoxin (MT81) from Penicillium nigricans on liver function in mice. Indian Drugs 1982; 19:430

33. Gupta M, Chatterjee T, Dattagupta S, Bagchi GK. Proceedings of the All India SympoSium on Mycotoxin. Bhagalpur University 1983; 103.

34. Gupta M, Chatterjee T. Indian J Pharmacol 1985; 17:195.
35. Maiti Choudhury S, Roy G, Gupta M, Majumder UK. The central nervous system depressant activities of Mycotoxin MT81 and its Acetylated and Benzoylated analogues. Al Ame en J Med Sci 2008; 1:104-14.

36. Gupta M, Majumdar UK, Ray MR, Mukhopadhayay DK. Inhibition of experimental murine tumors by MT81, a new mycotoxin from Penicillium nigricans. Neoplasma 1997; 44:329-33.

37. Clarkson BD, Burchenal JH. Preliminary seceening of antineoplasic drugs. Prog Clin Cancer 1965; 1:625-9.

38. Price VE, Greenfield RE. Anemia in cancer. Avd Cancer Res 1958; 5:199-200.

39. Hogland HC. Hemnatological complications of cancer chemotherapy. Semin Oncol 1982; 9:95-102.

40. Sun Y. Free radicals, antioxidant enzymes and carcinogenesis. Free Radic Biol Med 1990; 8:583-99.

41. Cerutti PA. Pro-oxidant ststus and tumor promossion. Science 1985; 227:375-81.

42. Fenninger LD, Mider GB. Energy and nitrogen metabolism in cancer. Avd Cancer Res 1954; 2:229-53.

43. Meister A. Glutathione metabolism and its selective modification. J Biochem 1988; 263:17205-8.

44. Mates JM, Perez-Gomez C, Nunez de Castro I. Antioxidant enzymes and human disease. Clin Biochem 1999; 32:595-603.

45. Gupta A, Batts B, Kwei Ka, Dvorakova K, Stratton Sp, Briehl MM, et al. Attenuation of catalase activity in the malignant phenotype plays a functional role in an in vitro model for tumor progression. Cancer Lett 2001; 73:115-25.

46. Yagi K. Lipid perosxides and human diseases. Chem Phys Lipids 1987; 45:337-51.

47. Sinclair AJ, Barnett AH, Lunie J. Free radical and autooxidant systems in health and disease. Br J Hosp Med 1990; 43:334-44.

48. Sun Y, Oberly LW, Elwell JH, Sierra Rivera E. Antioxidant enzyme activityes in normal and transformaes mice liver cells. Int J Cancer 1989; 44:1028-33.

49. Marklund SL, Westman NG, Lundgren E, Roos G. Copper-and-zinc-containing superoxide dismutase, managanese-containinh superoxide dismutase, catalase and glutathione peroxidase in normal and neoplastic human cell lines and normal human tissues. Cancer Res 1982; 42:1955-61.

50. Chaudhary SC, Alam MS, Siddiqui MS, Athar M. Perillyl alcohol attenuates Ras-ERK signaling to inhibit murine skin inflammation and tumorigenesis. Chem Biol Interact 2009; 179:145-53.

51. Sheeja KR, Kuttan G, Kuttan R. Cytotoxic and antitumor activity of Berberin. Amala Res Bull 1997; 17:736

52. Kavamani S, Manisenthil Kumar KT. Effect of methanal extract of Ericostemna littorate on Dalton's lymphoma. J Ethnopharmacol 2000; 71:349-52.

53. Mazumder UK, Gupta M, Maiti S, Mukherjee M. Atitumor activity of Hygroohilaspinasa on Ehrlich ascites carcinoma and sarcoma-180 induced mice. Indian J Expt Biol 1997; 35:473-7. 
54. Gupta M, Mazumder Uk, Rath N, Mukhopadhyay DK. Antitumor activity of methanolic extract of Cassia fistula L. seed against Ehrlich ascites carcinoma. L Erthnopharmacol 2000; 72:151-6.

55. Sur P, Ganguly DK. Tea plant root extract (TRE) as an antineoplastic agent. Planta Med 1994; 60:106-9.

56. D' Armour FE, Blood FR, Belden DA. The Manual for laboratory work in mammalian physiology. $3^{\text {rd }} \mathrm{ed}$. Chicago: The University of Chicago Press 1965; 4-6.

57. Wintrobe MM, Lee GR, Boggs DR, Bithel TC, Athens JW, Forester J. Clinical hematology. $5^{\text {th }}$ ed. Philadelphia $1961 ; 326$

58. Dacie JV, Lewis SM. Parctical hematology $2^{\text {nd }} e d$. London. J and A Churchill 1985; 38-48.

59. Ohkawa H, Onishi N, Yagi K. Assay foir lipid perxidation in animal tissue by thiobarbituric acid reaction. Anal Biochem 1979; 95:351-8.

60. Grifth Mindr P. Determination of glutathione and glutathione disulphide using glutathione reductase and 2-vinylpyridine. Anal Biochem 1998; 106:207-12.

61. Marklund S, Marklund G. Involvement of superoxide anion radical in the auto oxidation of pyrogallol and a convenient assay for superoxide dismutase. Eur J Biochem 1974; 47:469-74.

62. Aebi H. Catalase. In: Burgmeyer HU, editor. Methods of enzymatic analysis, vol 3, $3^{\text {rd }}$ ed. New York: Academic Press 1983; 273.

63. Lowry OH, Rosebrough NJ, Farr AL, Randall RJ Protein mesurment with the-phenol reagent. J Biol Chem 1951; 193:265-75 


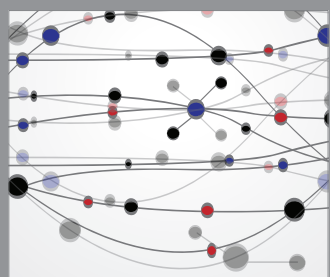

The Scientific World Journal
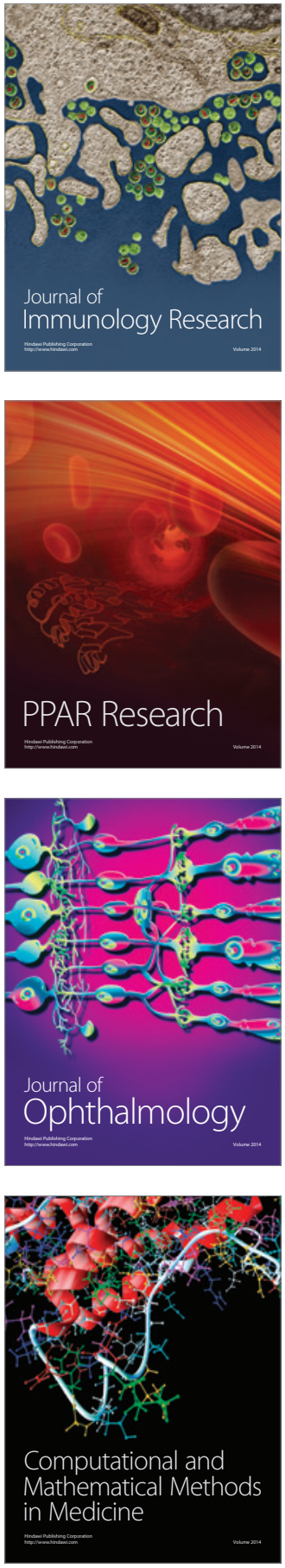

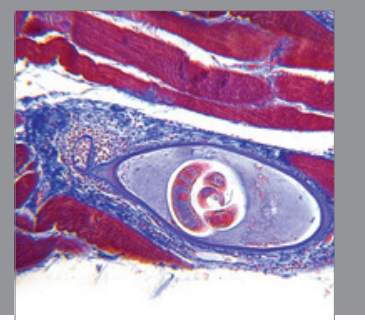

Gastroenterology

Research and Practice
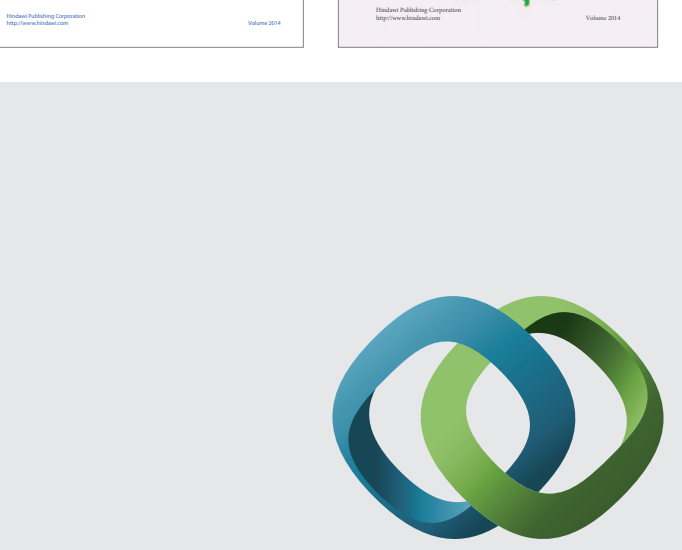

\section{Hindawi}

Submit your manuscripts at

http://www.hindawi.com
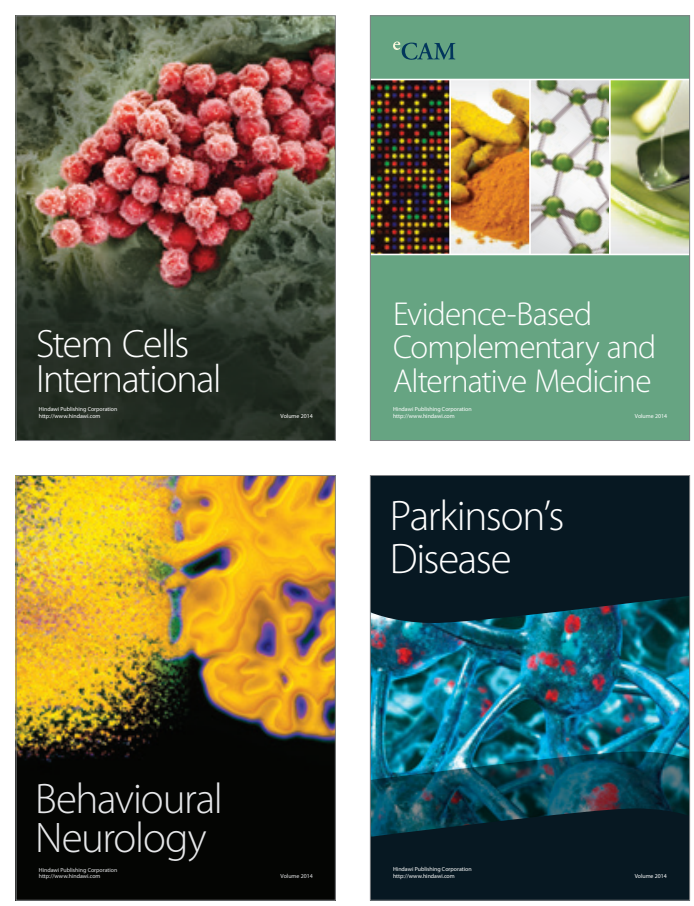

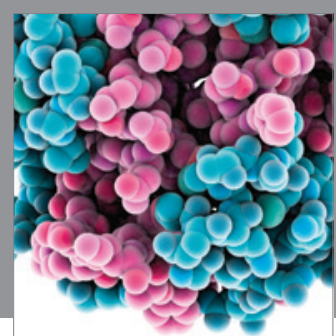

Journal of
Diabetes Research

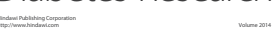

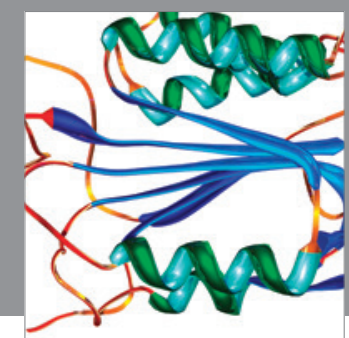

Disease Markers
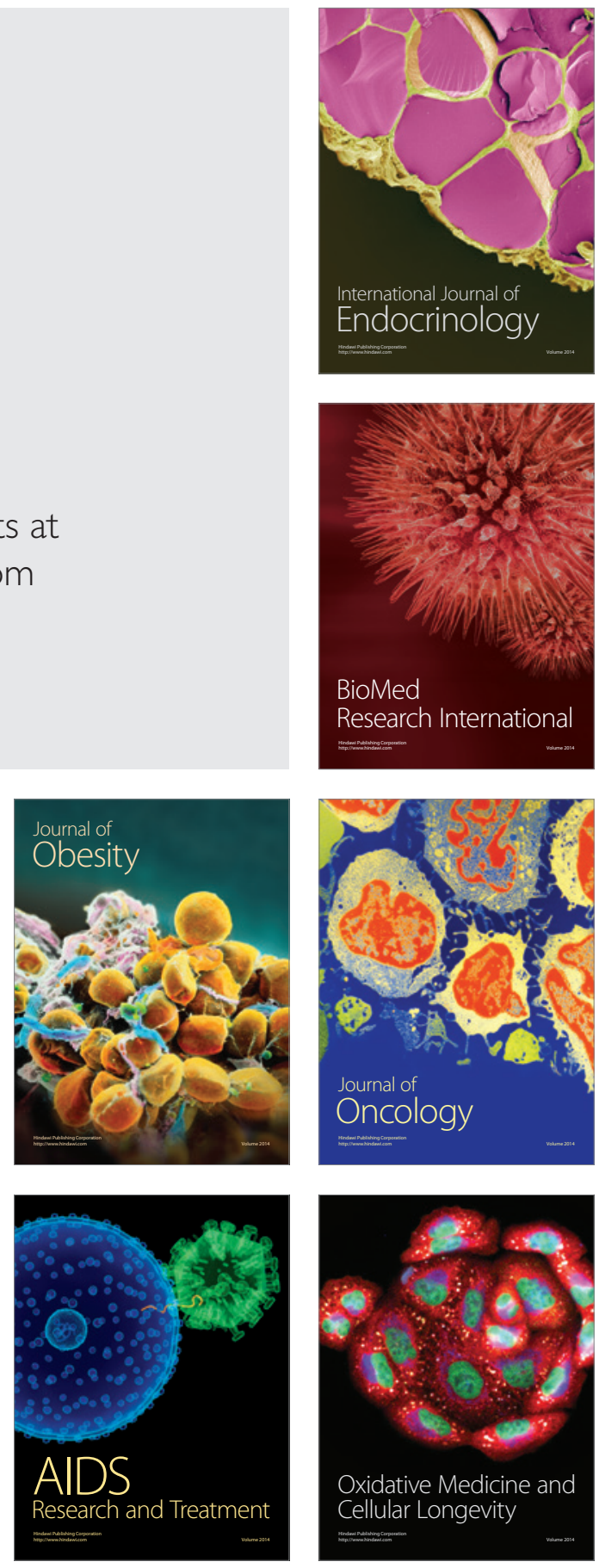